\title{
Assessment of total aflatoxins level of two major nuts consumed in Makurdi Benue State, Nigeria
}

\author{
S. T. Ubwa ${ }^{1}$, J. Abah ${ }^{2}$, B. O. Atu ${ }^{3}$, R. L. Tyohemba ${ }^{1}$, J. T. Yande ${ }^{1}$ \\ ${ }^{1}$ Department of Chemistry, Faculty of Science, Benue State University, P. M. B. 1026, Makurdi, Nigeria \\ ${ }^{2}$ Department of Mathematics, Science and Sport Education, Faculty of Education, University of Namibia, Katima Mulilo Campus, \\ Private Bag, 1096, Katima Mulilo, Namibia \\ ${ }^{3}$ Department of Biological Sciences, Faculty of Science, Benue State University, P. M. B. 1026, Makurdi, Nigeria
}

\section{Email address:}

drsimonterverubwa@gmail.com (S. T. Ubwa),jabah@unam.na (J. Abah), oyeonin@yahoo.com (B. O. Atu), raylubem@gmail.com (R. L. Tyohemba),yandejosefs@gmail.com (J. T. Yande)

\section{To cite this article:}

S. T. Ubwa, J. Abah, B. O. Atu, R. L. Tyohemba, J. T. Yande. Assessment of Total Aflatoxins Level of Two Major Nuts Consumed in Makurdi Benue State, Nigeria. International Journal of Nutrition and Food Sciences. Vol. 3, No. 5, 2014, pp. 397-403.

doi: $10.11648 /$ j.ijnfs.20140305.16

\begin{abstract}
The main aim of this study was to determine the total aflatoxin (TAF) contents of roasted cashew nuts (Anacardium occidentale), and the roasted, hulled and dehulled groundnuts (Arachis hypogaea L.) sold and consumed in the major public areas of Makurdi Benue State, Nigeria. The items were sampled from 10 different locations based on human traffic densities and sellers of the product and then analysed for TAF contents using direct competitive Enzymelinked Immunosorbent Assay (ELISA) method. In the roasted cashew nuts, TAF was only dectected in samples collected at two of the locations; Wadata New Garage $(0.10 \mu \mathrm{g} / \mathrm{kg})$ and High-Level $(0.40 \mu \mathrm{g} / \mathrm{kg})$ but not detected in samples collected at the eight others. However, the detected levels were below the maximum permissible limits (MPL) of $4 \mu \mathrm{g} / \mathrm{kg}$ set by EU and $10.0 \mu \mathrm{g} / \mathrm{kg}$ set by CAC and NAFDAC, Nigeria for 'ready to eat' food substances. In the roasted groundnuts, levels of TAF higher than the indicated MPL were recorded in samples collected at Modern Market $(12.00 \mu \mathrm{g} / \mathrm{kg})$ and Railway Market $(>20.00 \mu \mathrm{g} / \mathrm{kg})$ while similar result at North Bank $(5.60 \mu \mathrm{g} / \mathrm{kg})$ only exceeded the EU MPL. Only samples of hulled groundnuts collected at High-Level and Wurukum recorded TAF levels of $0.20 \mu \mathrm{g} / \mathrm{kg}$. Dehulled groundnuts sampled at Modern market $(13.10 \mu \mathrm{g} / \mathrm{kg})$ and Railway market $(>20.00 \mu \mathrm{g} / \mathrm{kg})$ recorded higher TAF levels than CAC and NAFDAC MPLs while similar result at North Bank $(6.20 \mathrm{ppb})$ only exceeded the EU MPL. Apart from the dehulled groundnuts samples collected at the Modern market sample location which recorded a moisture level of $5.84 \%$; all the other samples had moisture levels below the recommended maximum safe limits of $5.80 \%$ for stored groundnuts and cashew nuts. The results of microbial counts showed that total mesophilic bacteria varied between $<1.0 \times 10^{1}$ to $>1.0 \times 10^{2} \mathrm{CFU} / \mathrm{L}$, fungi varied between $<1.0 \times 10^{1}$ to $>1.0 \times 10^{1} \mathrm{CFU} / \mathrm{L}$ while E.coli counts varied between 0.00 to $0.43 \mathrm{CFU} / \mathrm{L}$. The microbial contamination was generally low. However, prolonged consumption of the TAF-contaminated nuts is possible in the study area due to the rising food insecurity of majority of the populace. The chronic exposure therefore, presents health concern of aflatoxicosis.
\end{abstract}

Keywords: Total Aflatoxins, Roasted Cashew Nuts, Roasted, Hulled and Dehulled Groundnuts, Microbial Count, Consumers

\section{Introduction}

Processed food substances such as bread, cakes, roasted cashew nuts, groundnuts, doughnuts, popcorn, biscuits etc highly consumed as fast foods in public places are often exposed to moisture and attack by pathogenic organisms such as moulds/fungi, bacteria and a protozoa. Moulds produce secondary metabolites known as mycotoxins which have attracted much attention recently as a result of their pathogenic roles [1]. The Food and Agricultural Organization (FAO) submitted that up to $25 \%$ of foodstuffs available Worldwide are contaminated with mycotoxins [2], with aflatoxins being identified as the most toxic of these mycotoxins. Research findings have shown that foodstuffs such as; fruits, cereals, nuts and tea which are exposed to 
fungal attack are often contaminated with aflatoxins $[3,4]$. Nuts are one of the most commonly consumed snacks globally but their poor handling has made them prone to aflatoxins cantamination and this poses a serious challenge for their safety and quality [1]. Groundnuts are often subsceptible to moulds infestation on the field, during storage (if not properly dried) and during processing and packaging as a result of which they are liable to contamination by afflatoxins $[5,6]$. Studies have shown that poor handling processes can increase the levels of aflatoxins contamination along the marketing chain $[7,8]$. Pest attacks were also noted to expidite mould inversion of some stored products [9].

Aflatoxins consists of four major types; B1, B2, G1, G2 and two other metabolic products; $\mathrm{M}_{1}$ and $\mathrm{M}_{2}$; these are significant in their contamination of foodstuffs and feeds. Aflatoxins $\mathrm{AFM}_{1}$ and $\mathrm{AFM}_{2}$ have $\mathrm{M}$-designation because they were first isolated from milk of lactating animals fed with aflatoxin preparations. The AFB1 and AFB2 were designated $\mathrm{B}$ because they exhibition blue fluorescence under UV-light while the AFG1 and AFG2 designation refers to those that give yellow-green fluorescence under UV-light [9]. AFB1 is most frequently found in plant materials, and shows the extreme toxigenic potential and hence, has been classified as a class 1A human carcinogen $[10,11]$.

Consumption of foods contaminated with fungal growth exposes humans to aflatoxins. Such exposures are not easy to avoid because of the difficulty of controlling fungal growth in foods [12]. It was also submitted that even though, heavily contaminated food supplies are not permitted in the market place in several countries, concern still remains for the possible adverse effects resulting from long-term exposure to low levels of aflatoxins in the food supply. Acute aflatoxicosis in humans has been reported in many third World Countries, like India, Taiwan and Uganda $[12,9]$. Aspergillus flavus, the main producer of aflatoxin, only grows in groundnuts when the moisture content exceeds $9 \%$ and has optimum growth temperature conditions of between $25^{\circ} \mathrm{C}$ and $30^{\circ} \mathrm{C}$ [13]. The warm and humid environmental conditions in Africa are ideal for the growth of A. flavus making aflatoxin contamination of food, including groundnuts, a widespread problem across the continent [14 -16].

Aflatoxins are extremely persistent under most conditions of storage, handling and processing of foods. It is, therefore, impossible to eliminate them once the foodstuffs are contaminated $[2,3,6]$. Nuts aflatoxins are not affected by temperature and remain active even at $160^{\circ} \mathrm{C}$ [17]. There are a lot of groundnuts, cashew nuts, maize, rice, among other food substances in Benue State, that are susceptible to contamination by aflatoxins because of the critical conditions of high temperature and humidity that are known to favour the growth of aflatoxin-producing moulds. The groundnuts and cashew nuts in particular, as well as their products are the most traded snacks by food vendors in Benue State and are widely consumed in all seasons by several persons (including travellers, students, traders, as well as people in public places; parks, markets, supermarkets, schools, work places including farms). This study was therefore, conducted with the objective of determining the total aflatoxin levels of roasted cashew nuts and the roasted, hulled and dehulled groundnuts traded in the commercial city of Makurdi, Benue State.

\section{Materials and Method}

\subsection{Study Area}

The study was carried out in Makurdi, the capital of Benue State-Nigeria. The city is located at the North Eastern part of Benue State and lies on latitude $7^{\circ} 30^{\prime} \mathrm{N}$ and longitude $8^{\circ} 35^{\prime} \mathrm{E}$, and an elevation of $104 \mathrm{~m}$ above sea level with about 300,377 inhabitants [18]. Makurdi lies in the tropical guinea savanna zone of the Central Nigeria and has a typical climate with two distinct seasons: the dry season (often lasts from November to March) and rainy season (April to October). The area has a mean annual rainfall of $1000 \mathrm{~mm}$ and temperature fluctuates between a minimum of $27^{\circ} \mathrm{C}$ to $28^{\circ} \mathrm{C}$ and a maximum of $30^{\circ} \mathrm{C}$ to $34^{\circ} \mathrm{C}$ [19]. Roasted and hulled Groundnuts as well as roasted cashew nuts are among the most traded snacks throughout the season in Makurdi and the business is favoured by the high population and commercial activities of the town. However, the high temperature and humidity of the area are important climatic conditions for incidence of aflatoxin contaminations of poorly processed and handled foodstuff such nuts, corns, cakes which consitute high proportion of food vendors' commodities in the city.

\subsection{Sample Collection and Pretreatment}

Ten (10) sampling stations were identified in Makurdi metropolis namely: High-Level, Wurukum, North-Bank, Modern market, Railway market, Police check point (Makurdi Airport), Benue State University (BSU) labour market, Filling stations, Kanshio Mechanic village and Wadata New garage. In each sampling stations, five substations were systematically selected based on the high concnetrations of human traffic and sellers of the roasted, hulled and dehulled groundnuts as well as roasted cashew nuts. Apart from three sample stations: Police check point (Makurdi Airport), BSU labour market and Filling stations where raw groundnut samples (hulled and dehulled) were not obtainable at the time of collecting the samples; two samples of each item were collected at random from each sub-station, making a total of 10 roasted groundnuts, 10 hulled groundnuts, 10 dehulled groundnuts and 10 roasted cashew nuts respectively. The total samples of each nut per sampling station were pooled together into one composite and mixed thorougly after which 3 respresentative samples were taken for each station and taken for laboratory preparation and analyses for the moisture contents, total aflatoxin levels, and fungi (mould)/bacteria counts. In all, the representative samples consisted of 10 roasted cashew 
nuts, 10 roasted groundnuts, 7 hulled groundnuts and 7 dehulled groundnuts. The hulled groundnuts were manually dehulled to obtain the nuts used for further processing and analysis.

\subsection{Determination of Moisture Content}

A measured amount $(5.0 \mathrm{~g})$ of each representative sample was pulverised using a Romer series II Miller. Then, $3.0 \mathrm{~g}$ of each pulverised sample was weighed into aluminium moisture plate and placed on the tray after which the lid was closed. Moisture content analyser, Sartorius, M100 certified according to ISO9001 was used. Running the analysis commenced when the button "Run analysis" was entered, and after waiting a while, alarm triggered, indicating the end of the analysis. The analysis was completed at the temperature of $105^{\circ} \mathrm{C}$ and the results displayed on the digital screen in percentage (\%) was recorded.

\subsection{Determination of the Total Aflatoxin Levels}

\subsubsection{Samples Preparation}

Twenty grams (20.0 g) of each composite sample was ground using a Romer series II Miller and sieved through a 20 -mesh screen. Then, $15.0 \mathrm{~g}$ of the sieved sample was weighed into a pre-cleaned jar followed by the addition of $100 \mathrm{~mL}$ of $70 / 30(\mathrm{v} / \mathrm{v})$ methanol-water extraction solution and the jar was sealed. A 1:5 (w:v) of the sample to extraction solution was mixed and shaken vigorously for 3 minutes and then allowed to settle. Thereafter, the supernatant was filtered through a whatman No. 1 filter paper and the filtrate collected [20].

\subsubsection{Assay by the AgraQuant Total Aflatoxin Method}

The filtrate was then mixed with enzyme-conjugated aflatoxins after which antibody-coated micro-well was also added. This allows the aflatoxins in the sample to compete with the enzyme-conjugated aflatoxins for the antibody binding sites [20].

After a washing step, an enzyme substrate was added and blue colour developed. The concentration of aflatoxin in the sample was determined by observing the intensity of the colour (intensity of the colour is inversely proportional to the concentration of aflatoxin in the sample or standard) [20]. A "stop solution" was then added which changed the colour from blue to yellow. The micro-wells were measured optically using a micro-well reader with an absorbance filter of optical density, $450 \mathrm{~nm}\left(\mathrm{OD}_{450}\right)$, and a differential filter of $630 \mathrm{~nm}$. The optical densities (ODs) of the samples were compared to the ODs of the standards and an interpretative result was determined [20].

\subsubsection{Assay of the AgraQuant Total Aflatoxin Method}

Sixteen blue/green-bordered dilution strips were placed in a microwell strip holder. Separate dilution well was used for each standard $(0.0,2.0,4.0,10.0$ and $20.0 \mathrm{ppb})$ and the sample. Then, an equal numbers of Antibody Coated Microwell (ACM) strips were placed in the holder. Using an 8-channel pipettor, $2.0 \mathrm{~mL}$ of conjugate was dispensed into each blue/green-bordered dilution well. Further, using separate single channel pipettor, $1.0 \mathrm{~mL}$ of the substrate and standard were respectively dispensed into each corresponding microwell strip containing the conjugate. A fresh 8-channel pipettor was used to mix the sample by carefully pipetting it up and down three times and immediately, $1 \mathrm{ml}$ of the mixture was transferred into the antibody coated microwell strips and incubated for 15 minutes at room temperature. The antibody coated microwell strips were then emptied and washed five times with deionised water. Maximum care was taken not to dislodge the strips from the holder during the washing process [20]. Then, for each microwell strip, absorbent paper towels were folded into several layers, laid on a flat surface and the strip tapped onto the towels to absorb as much residual water as possible before drying the bottom with a dry-towel. Using the 8-channel pipettor, $1 \mathrm{ml} / \mathrm{strip}$ portion of the substrate was put into the microwell strips and incubated for 5 minutes [20]. Then, using a fresh 8channel pipettor, $1.0 \mathrm{~mL}$ of "stop solution" was pipetted into each microwell strip and the colour changed from blue to yellow. Thereafter, the strips were read with a microwell reader using a $450 \mathrm{~nm}$ filter and a differential filter of 630 $\mathrm{nm}$. The Optical Density (OD) readings were recorded for each micro-well.

\subsubsection{Interpretation of Results with the Romer AgraQuant Total Aflatoxin Assay Method}

The OD values were each expressed as a percentage of the OD of the zero (0.0) standard and then a dose-response curve was constructed using the five standards. Since the amount of aflatoxin in each standard was known, the unknown was measured by interpolation from this standard curve. Results were further calculated using the Romer Log/Logit spreadsheet and the Log/Logit regression model was used for the results interpretation; the linearity coefficient $\left(r^{2}\right)$ of the calibration curve was not less than $0.985[20]$.

\subsubsection{Isolation of Moulds and Microbial Counts}

The procedure described below was followed for the isolation of moulds from each sample. Four pre-cleaned bottles were labelled with arbitrary letters $\mathrm{u}$ to $\mathrm{x}$ and the solutions they contained were respectively identified by the labels. Then, $5.0 \mathrm{~g}$ of each sample was mashed and transferred into the bottle, ' $\mathrm{u}$ ' containing $45 \mathrm{~mL}$ of peptone water and shaken thoroughly to mix. With a sterile syringe, $2.0 \mathrm{~mL}$ of solution $\mathrm{u}$ was transferred into another bottle, ' $\mathrm{v}$ ' containing $18.0 \mathrm{~mL}$ peptone water and again shaken properly to mix. A $2.0 \mathrm{~mL}$ of solution $\mathrm{v}$ was transferred into another bottle, 'w', also containing $18.0 \mathrm{~mL}$ peptone water and mixed after which $1.0 \mathrm{~mL}$ of the solution $\mathrm{w}$ was transferred into a set of duplicate petri dishes labelled (1A, $\left.1 \mathrm{~A}^{\prime}\right)$. Then, $2.0 \mathrm{~mL}$ of solution $\mathrm{w}$ was transferred into another bottle, ' $\mathrm{x}$ ' containing $18.0 \mathrm{~mL}$ peptone water, mixed and $1.0 \mathrm{~mL}$ of solution $\mathrm{w}$ was transferred into another set of duplicate petri dishes (1B, 1B'). Then, $50 \mathrm{~mL}$ 
Durhan tubes were filled with $40 \mathrm{~mL}$ MacConkey Broth (MCB) by gently tilting, ensuring that no air bubble was trapped in the broth. When the molten Sabourand Dextrose Agar (SDA) cooled to about $54^{\circ} \mathrm{C}, 10.0 \mathrm{~mL}$ of the molten Agar was transferred into each of the petri dishes and gently swirled to mix. Another $10.0 \mathrm{~mL}$ of the Agar was taken into a control petri dish (C), and allowed to set/gel. Then, the petri dishes were incubated in an incubator, set at $37^{\circ} \mathrm{C}$ for $48 \mathrm{hrs}$ after which the microbial growth were examined microscopically using Lacto-phenol Cotton Blue (LPCB) stain and classified by reporting the culture characteristics at the face and reverse side of the inoculated Petri dishes [21]. The results were determined in units of colony-forming unit per millilitre (CFU/mL).

\section{Results and Discussion}

\subsection{Moisture Content}

The results of moisture contents (\%) of the roasted cashew nuts, and the roasted, hulled and dehulled groundnuts sampled at ten locations within Makurdi metropolis are as presented in Table 1. Moisture levels of the roasted cashew nuts varied between $2.19 \%$ to $2.76 \%$ while roasted groundnuts recorded moisture levels of $1.80 \%$ to $4.20 \%$.

Table 1. Moisture contents of roasted cashew nuts, roasted, hulled and dehulled groundnuts sold in Makurdi metropolis

\begin{tabular}{|c|c|c|c|c|c|}
\hline \multirow{3}{*}{$\mathbf{S} / \mathbf{N}$} & \multirow{3}{*}{ Sampling Station } & \multicolumn{4}{|c|}{ Moisture content $(\%)$} \\
\hline & & \multirow{2}{*}{$\begin{array}{l}\text { Cashew nuts } \\
\text { Roasted }\end{array}$} & \multicolumn{3}{|c|}{ Groundnuts } \\
\hline & & & Roasted & Hull & Dehulled \\
\hline 1 & High Level & 2.74 & 3.04 & 4.13 & 5.22 \\
\hline 2 & Wurukun & 2.19 & 3.13 & 4.20 & 5.45 \\
\hline 3 & North Bank & 2.32 & 3.45 & 3.80 & 5.77 \\
\hline 4 & Modern Market & 2.22 & 3.25 & 3.56 & 5.84 \\
\hline 5 & Railway Market & 2.24 & 4.02 & 4.00 & 4.95 \\
\hline 6 & Police Check-point & 2.30 & 2.50 & - & - \\
\hline 7 & BSU Labour Market & 2.21 & 1.80 & - & - \\
\hline 8 & Filing Station & 2.25 & 2.01 & - & - \\
\hline 9 & Kanshio Mechanic Village & 2.20 & 2.27 & 4.02 & 4.27 \\
\hline 10 & Wadata New Garage & 2.76 & 2.08 & 3.45 & 3.80 \\
\hline
\end{tabular}

Similar results for the hulled and dehulled groundnuts varied between $3.45 \%$ to $4.20 \%$ and $3.80 \%$ to $5.84 \%$ respectively. Apart from the moisture level of the dehulled groundnuts sample collected at Modern market (5.84\%), the general levels of the results across the sampling points did not exceed the maximum recommended moisture limit of $5.80 \%$ for safe storage of nuts [22]. Thus, this indicates that under proper conditions of storage and handling, the present moisture levels of the cashew nuts and groundnuts (roasted, hulled and dehulled) sold across the sampling stations in Makurdi do not present favourable growth condition for moulds and hence, aflatoxin infestation.

\subsection{Total Aflatoxin Level of the Roasted Cashew Nuts, Roasted, Hulled and Dehulled Groundnuts}

The results of the total aflatoxin (TAF) levels of the roasted cashew nuts, and the roasted, hulled and dehulled groundnuts sampled at ten locations within Makurdi metropolis are as presented in Table 2. The roasted cashew nuts recorded total aflatoxin contents of $0.10 \mu \mathrm{g} / \mathrm{kg}$ and $0.40 \mu \mathrm{g} / \mathrm{kg}$ at only two sampling points (Wadata New garage and High-Level). These results reflect a good processing, handling and storage conditions of the roasted cashew nuts since the recorded moisture levels of 2.19 to $2.76 \%$ do not represent a favourable growth condition for moulds that produce aflatoxins in stored foodstuffs. Results of the TAF contents of the roasted groundnuts revealed that samples collected at North-Bank location recorded 5.60 $\mu \mathrm{g} / \mathrm{kg}$ which exceeded the EU maximum permissible limit
(MPL) of $4.0 \mu \mathrm{g} / \mathrm{kg}$ for nuts $[23,24]$. At the Modern and Railway markets, roasted groundnuts recorded TAF levels of $12.0 \mu \mathrm{g} / \mathrm{kg}$ and $>20.0 \mu \mathrm{g} / \mathrm{kg}$ respectively, which exceeded the MPLs of both EU and $10.0 \mu \mathrm{g} / \mathrm{kg}$ set by Codex Alimentarius Commission, CAC [24], and the National Agency for Food and Drug Administration and Control, NAFDAC Nigeria [25] for 'ready to eat' food substances. These results suggest poor processing and handling of the product at these locations, which has health implications of aflatoxicosis for the consumers. In the study area where food insecurity is a major concern, aflatoxin contaminated food poses a serious threat since greater part of the population is ravaged by poverty and have little choice of the kind of food they consume. Many deaths resulting from liver failure occur yearly in our hospitals and homes and these may be traced to the under-recognized and under-reported cases of acute aflatoxicosis [26]. Aflatoxins exposures have been reported to be responsible for the cause of deaths resulting from liver cancer in about 26,000 Africans living south of the Sahara annually [27]. WHO's report also indicated that exposure of children to aflatoxins is a contributory element of stunted growth, underweight, neurological disorder, immuno- suppression and death. The ability of aflatoxins to cause immuno-suppression suggests that it could interact with HIV/AIDS. Furthermore, diseases caused by mycotoxins have been reported to reduce life expectancy in Africa where nutritional needs tend to surpass other concerns such as food safety [26]. However, similar results obtained in the roasted groundnuts samples collected at High-Level $(1.20 \mu \mathrm{g} / \mathrm{kg})$, Wurukun $(1.90 \mu \mathrm{g} / \mathrm{kg})$ 
and Airport Police check point $(0.30 \mu \mathrm{g} / \mathrm{kg})$ were lower than the reported regulatory limits. Additionally, total aflatoxins were not detected in the samples collected at BSU labour market, Filling stations, Kanshio Mechanic village and Wadata New garage. This suggests a better processing and handling of the product at these locations. In the hull groundnuts, only samples collected at HighLevel and Wurukum locations recorded TAF contents of $0.20 \mu \mathrm{g} / \mathrm{kg}$ each. The dehulled groundnuts showed levels of total aflatoxin contamination exceeding the regulatory limits in samples collected at the Railway market $(>20.0$ $\mu \mathrm{g} / \mathrm{kg})$, Modern market $(13.10 \mu \mathrm{g} / \mathrm{kg})$ and North-Bank location $(6.20 \mu \mathrm{g} / \mathrm{kg})$. However, the samples collected at Wurukum recorded $2.30 \mu \mathrm{g} / \mathrm{kg}$, High-Level; $1.50 \mu \mathrm{g} / \mathrm{kg}$ and Kanshio Mechanic Village; $0.60 \mu \mathrm{g} / \mathrm{kg}$ which were lower than the indicated MPLs. At Wadata New garage, aflatoxin was not detected in the dehulled groundnuts samples. At the time of this study, both hulled and dehulled groundnuts were not obtainable at the Police check point (Makurdi Airport), BSU labour market and Filling stations.

Table 2. Total aflatoxin concentrations in roasted cashew nuts, roasted, hulled and dehulled groundnuts sold in Makurdi metropolis

\begin{tabular}{|c|c|c|c|c|c|}
\hline \multirow{3}{*}{$\mathbf{S} / \mathbf{N}$} & \multirow{3}{*}{ Sampling Station } & \multicolumn{4}{|c|}{ Aflatoxin concentration $(\mu \mathrm{g} / \mathrm{kg})$} \\
\hline & & \multirow{2}{*}{$\begin{array}{l}\text { Cashew nuts } \\
\text { Roasted } \\
\end{array}$} & \multicolumn{3}{|c|}{ Groundnuts } \\
\hline & & & Roasted & Hull & Dehulled \\
\hline 1 & High Level & 0.40 & 1.20 & 0.20 & 1.50 \\
\hline 2 & Wurukun & ND & 1.90 & 0.20 & 2.30 \\
\hline 3 & North Bank & ND & 5.60 & ND & 6.20 \\
\hline 4 & Modern Market & ND & 12.00 & ND & 13.10 \\
\hline 5 & Railway Market & ND & $>20.00$ & ND & $>20.00$ \\
\hline 6 & Police Check-point & ND & 0.30 & - & - \\
\hline 7 & BSU Labour Market & ND & ND & - & - \\
\hline 8 & Filing Station & ND & ND & - & - \\
\hline 9 & Kanshio Mechanic Village & ND & ND & ND & 0.60 \\
\hline 10 & Wadata New Garage & 0.10 & ND & ND & ND \\
\hline
\end{tabular}

$\mathrm{ND}=$ Not detected

\subsection{Microbial Counts of the Roasted Cashew Nuts, Roasted, Hull and Dehulled Groundnuts}

The results presented in Tables $3-6$ show the microbial contaminations of the roasted cashew nuts as well as roasted, hulled and dehulled groundnuts sold in Makurdi metropolis. In the roasted cashew nuts (Table 3 ), the results showed total mesophilic bacteria counts varying between $<$ $1.0 \times 10^{1}$ to $>1.0 \times 10^{1} \mathrm{CFU} / \mathrm{L}$, fungal counts of $<1.0 \times 10^{1}$ to $>1.0 \times 10^{1} \mathrm{CFU} / \mathrm{L}$, and E. coli counts of 0.00 to 0.01 CFU/L. The roasted groundnuts recorded total mesophilic bacteria counts ranging between $<1.0 \times 10^{1}$ to $2.9 \times 10^{1}$ $\mathrm{CFU} / \mathrm{L}$, fungal counts of $7.8 \times 10^{0}$ to $<1.0 \times 10^{1} \mathrm{CFU} / \mathrm{L}$ while the results of E.coli counts was $0.00 \mathrm{CFU} / \mathrm{L}$. The results of the microbial counts obtained in the hulled groundnuts varied between $<1.0 \times 10^{1}$ to $>1.0 \times 10^{2} \mathrm{CFU} / \mathrm{L}$ total mesophilic bacteria counts, $<1.0 \times 10^{1}$ to $>1.0 \times 10^{1}$ $\mathrm{CFU} / \mathrm{L}$ fungi counts while $E$. coli. was not seen. In the dehulled groundnuts, the results revealed that total mesophilic bacteria counts varied between $>1.0 \times 10^{2}$ to $<1.0 \times 10^{1} \mathrm{CFU} / \mathrm{L}$ while fungi and E.coli counts recorded $<1.0 \times 10^{1}$ to $>1.0 \times 10^{1} \mathrm{CFU} / \mathrm{L}$ and $0.00 \mathrm{CFU} / \mathrm{L}$ respectively. Generally, the roasted samples have reduced levels of microbial counts and this may be attributed to the effect of roasting and salting during processing which helped in preserving these nuts.

Table 3. Microbial counts (CFU/mL) of the roasted cashew nuts sold in Makurdi metropolis

\begin{tabular}{|c|c|c|c|c|}
\hline $\mathbf{S} / \mathbf{N}$ & Sampling Station & Total mesophilic bacteria & Fungi & E.coli \\
\hline 1 & High Level & $<1.0 \times 10^{1}$ & $<1.0 \times 10^{1}$ & 0.00 \\
\hline 2 & Wurukun & $<1.0 \times 10^{1}$ & $<1.0 \times 10^{1}$ & 0.00 \\
\hline 3 & North Bank & $<1.0 \times 10^{1}$ & $<1.0 \times 10^{1}$ & 0.00 \\
\hline 4 & Modern Market & $<1.0 \times 10^{1}$ & $<1.0 \times 10^{1}$ & 0.00 \\
\hline 5 & Railway Market & $<1.0 \times 10^{1}$ & $<1.0 \times 10^{1}$ & 0.00 \\
\hline 6 & Police Check-point & $>1.0 \times 10^{1}$ & $>1.0 \times 10^{1}$ & 0.01 \\
\hline 7 & BSU Labour Market & $>1.0 \times 10^{1}$ & $>1.0 \times 10^{1}$ & 0.00 \\
\hline 8 & Filing Station & $<1.0 \times 10^{1}$ & $<1.0 \times 10^{1}$ & 0.00 \\
\hline 9 & Kanshio Mechanic Village & $>1.0 \times 10^{1}$ & $>1.0 \times 10^{1}$ & 0.00 \\
\hline 10 & Wadata New Garage & $<1.0 \times 10^{1}$ & $<1.0 \times 10^{1}$ & 0.00 \\
\hline
\end{tabular}


Table 4. Microbial counts (CFU/mL) of the roasted groundnuts sold in Makurdi metropolis

\begin{tabular}{lllll}
\hline S/N & Sampling Station & Total mesophilic bacteria & Fungi & E.coli \\
\hline 1 & High Level & $<1.0 \times 10^{1}$ & $<1.0 \times 10^{1}$ & 0.00 \\
2 & Wurukun & $2.9 \times 10^{1}$ & $7.8 \times 10^{0}$ & 0.00 \\
3 & North Bank & $>1.0 \times 10^{1}$ & $>1.0 \times 10^{1}$ & 0.00 \\
4 & Modern Market & $>1.0 \times 10^{1}$ & $>1.0 \times 10^{1}$ & 0.00 \\
5 & Railway Market & $>1.0 \times 10^{1}$ & $>1.0 \times 10^{1}$ & 0.00 \\
6 & Police Check-point & $>1.0 \times 10^{1}$ & $>1.0 \times 10^{1}$ & 0.00 \\
7 & BSU Labour Market & $>1.0 \times 10^{1}$ & $<1.0 \times 10^{1}$ & 0.00 \\
8 & Filing Station & $<1.0 \times 10^{1}$ & 0.00 \\
9 & Kanshio Mechanic Village & $1.0 \times 10^{1}$ & $1.0 \times 10^{1}$ & 0.00 \\
10 & Wadata New Garage & $>1.0 \times 10^{1}$ & $>1.0 \times 10^{1}$ & 0.00 \\
\hline
\end{tabular}

Table 5. Microbial counts (CFU/mL) of the hulled groundnuts sold in Makurdi metropolis

\begin{tabular}{lllll}
\hline $\mathbf{S} / \mathbf{N}$ & Sampling Station & Total mesophilic bacteria & Fungi & E.coli \\
\hline 1 & High Level & $<1.0 \times 10^{1}$ & $<1.0 \times 10^{1}$ & 0.00 \\
2 & Wurukun & $<1.0 \times 10^{2}$ & $<1.0 \times 10^{1}$ & 0.00 \\
3 & North Bank & $>1.0 \times 10^{1}$ & $>1.0 \times 10^{1}$ & 0.00 \\
4 & Modern Market & $>1.0 \times 10^{1}$ & $>1.0 \times 10^{1}$ & 0.00 \\
5 & Railway Market & $>1.0 \times 10^{1}$ & $>1.0 \times 10^{1}$ & 0.00 \\
6 & Police Check-point & - & - & - \\
7 & BSU Labour Market & - & - & - \\
8 & Filing Station & - & $>1.0 \times 10^{1}$ & - \\
9 & Kanshio Mechanic Village & $>1.0 \times 10^{2}$ & $>1.0 \times 10^{1}$ & 0.00 \\
10 & Wadata New Garage & $<1.0 \times 10^{1}$ & & 0.00 \\
\hline
\end{tabular}

Table 6. Microbial counts (CFU/mL) of dehulled groundnuts sold in Makurdi metropolis

\begin{tabular}{lllll}
\hline S/N & Sampling Station & Total mesophilic bacteria & Fungi & E.coli \\
\hline 1 & High Level & $>1.0 \times 10^{1}$ & $>1.0 \times 10^{1}$ & 0.00 \\
2 & Wurukun & $>1.0 \times 10^{1}$ & $>1.0 \times 10^{1}$ & 0.00 \\
3 & North Bank & $>1.0 \times 10^{2}$ & $>1.0 \times 10^{1}$ & 0.00 \\
4 & Modern Market & $>1.0 \times 10^{1}$ & $>1.0 \times 10^{1}$ & 0.00 \\
5 & Railway Market & $>1.0 \times 10^{1}$ & - & 0.00 \\
6 & Police Check-point & - & - & - \\
7 & BSU Labour Market & - & - & - \\
8 & Filing Station & $<1.0 \times 10^{1}$ & 0.00 \\
9 & Kanshio Mechanic Village & $>1.0 \times 10^{1}$ & $>1.0 \times 10^{1}$ & 0.00 \\
10 & Wadata New Garage & & & \\
\hline
\end{tabular}

\section{Conclusion}

The results of this study revealed that the cashew nuts consumed within Makurdi metropolis recorded low levels of total aflatoxin (TAF) at only two sampling stations: Wadata New garage and High-Level but not detected in similar samples collected at the other locations. The detected levels were below the maximum permissible limits set by EU, CAC and NAFDAC, Nigeria for 'ready to eat' food substances. In the roasted groundnuts however, higher TAF levels than the permissible limits were recorded in samples collected at North-Bank, Modern and Railway markets respectively. However, no record of TAF was obtained in the roasted groundnuts samples collected at BSU labour market, Filling stations, Kanshio mechanic village and Wadata New garage. Samples of hulled groundnuts collected at High-Level and Wurukum recorded low levels of TAF while it was not detected in similar samples at the other locations. Dehulled groundnuts recorded higher TAF levels beyond the MPLs at NorthBank, Modern market and Railway market while lower level was recorded in the Kanshio mechanic village samples. Apart from the dehulled groundnuts samples collected at the Modern market sample location which recorded higher moisture value than the recommended maximum limit for stored groundnuts and cashew nuts; all the other samples recorded moisture levels below the recommended maximum limits of $5.80 \%$. The results of microbial counts showed low contamination levels of total mesophilic bacteria, fungi and E. coli. However, the nuts with higher TAF content above the health regulatory limits could present concern of aflatoxicosis to consumers following prolonged ingestion. Therefore, it is important that producers and traders of these popular staple diets are sensitized on good manufacturing and handling practices of the nuts to curb the contamination by aflatoxins, and other mycotoxins. 


\section{References}

[1] Ostadrahimi, A., Ashrafnejad, F., Kazemi, A., Sargheini, N., Mahdavi, R., Farshchian, M. and Mahluji, S. (2014). Aflatoxin in raw and salt-roasted nuts (pistachios, peanuts and walnuts) sold in markets of Tabriz, Iran, Jundishapur $J$ Microbiol. 7(1):e8674, 1-5. DOI: 10.5812/jjm.8674.

[2] Kabak, B. (2010). Prevention and Management of Mycotoxins in Food and Feed. Mycotoxins in Food, Feed and Bioweapons.part 2, 201-27.

[3] Wang, J. and Liu, X.M. (2007). Contamination of aflatoxins in different kinds of foods in China. Biomed Environ Sci. 2007;20(6):483-7.

[4] Soubra, L., Sarkis, D., Hilan, C. and Verger, P. (2009). Occurrence of total aflatoxins, ochratoxin $\mathrm{A}$ and deoxynivalenol in foodstuffs available on the Lebanese market and their impact on dietary exposure of children and teenagers in Beirut. Food Addit Contam Part A Chem Anal Control Expo Risk Assess. 26(2), 189-200.

[5] Polixeni, V. and Panagiota, M. (2008). Aflatoxin B1 and ochratoxin A in breakfast cereals from Athens market: Occurrence and risk assessment. Lab of food chemistry, Department of chemistry, University of Athens, Panepistimiopolis, 15784 Athens, Greece.

[6] Mutegi, C.K., Ngugi, H.K., Hendriks, S.L. and Jones, R.B. (2012). Factors associated with the incidence of Aspergillus section Flavi and aflatoxin contamination of peanuts in the Busia and Homa bay districts of western Kenya. Plant Pathology 61, 1143 - 1153.

[7] Kladpan, S., Mahakachanakul, W., Yongmanitchai, V.,

[8] Boonyaratanakornkit, M. and Chinbuti, A. (2004). Situation of aflatoxin contamination in groundnut products in Thailand in 2004. Proceedings of the 43rd Kasetsart University annual conference, Thailand, 1-4 February, 2005. pp. $557-564$.

[9] Kaaya, A.N., Harris, C. and Eigel, W. (2006). Peanut aflatoxin levels on farms and in markets of Uganda. Peanut Science 33: $68-75$.

[10] Cornell University (2014). AFLATOXINS: Occurrence and Health

Risks, http://www.ansci.cornell.edu/plants/toxicagents/aflatoxin/afl atoxin.html\#Monitoring. Accessed: 8/6/2014.

[11] Moss, M.O. (1998). Recent studies of mycotoxins. J. Appl. Microbiol-Symposium Suppl. 84, 62S-76S.

[12] Rothschild, L.J. (1992). IARC classes AFB1 as class 1 human carcinogen. Food Chem. News 1992, 34, 62-66.

[13] Environment, Health and Safety Online (EHSO), (2014). Aflatoxins in Your Food - and their Effect on Your Health. http://www.ehso.com/ehshome/aflatoxin.php Accessed: $8 / 6 / 2014$.

[14] Ribeiro, J., Cavaglieri, L., Fraga, M., Direito, G., Dalcero, A. and Rosa, C. (2006). Influence of water activity, temperature and time on mycotoxins production on barley rootlets. Letters in Applied Microbiology 42, 179 - 184.

[15] Gordon, S.S. (2003). Aflatoxin and food safety: Recent African perspectives. Promec Unit, Medical Research Council, Tygerberg, South Africa. Journal of Toxicology Toxin Reviews 22, $264-268$.

[16] Bankole, S.A., Schollenberger, M. and Drochner, W. (2006). Mycotoxin contamination in food systems in sub-Saharan Africa: A review. Mycotoxin Research 22, 163 - 169.

[17] Wagacha, J.M. and Muthomi, J.W. (2008). Mycotoxin problem in Africa: Current status, implications to food safety and health and possible management strategies International Journal of Food Microbiology 124, 1- 12.

[18] Yazdanpanah, H., Mohammadi, T., Abouhossain, G. and Cheraghali, A.M. (2005). Effect of roasting on degradation of aflatoxins in contaminated pistachio nuts. Food Chem Toxicol. 43(7), 1135-9.

[19] National Population Commission (2006). National Population Census. Federal Republic of Nigeria Official Gazette, 96 (2).

[20] Amuta, E., Houmsou, R. and Mker, S. (2008). Impact of socio-demographic and economic factors on the prevalence of intestinal parasites among the female gender in Makurdi, Benue State-Nigeria. The Internet Journal of Third World Medicine. 8(2).

[21] AgraQuant Total aflatoxin Assay1/20, Romer Labs Methods.(2013) Web: http://www.romerlabs.com. Accessed; $23 / 03 / 2014$

[22] Cheesbrough, M. (1984). Medical laboratory manual for tropical countries, $5^{\text {th }}$ ed. Great Britain at the University Press, Cambridge.

[23] Adebajo, L.O. and Diyaolu, S.A. (2003). Mycology and spoilage of retail cashew nuts. African Journal of Biotechnology,2(10):369-373.

[24] EU (2010). EU-27 New EU aflatoxin levels and sampling plan, gain.fas.usda.gov/.../New\%20EU\%20Aflatoxin\%20Levels\% 20and\%20Sa... Accessed; 8/06/2014

[25] European Food and Safety Authority, EFSA (2013). Aflatoxin in food, www.efsa.europa.eu > ... > Mycotoxins, Accessed; 07/07/2014.

[26] Kubo, M. (2012). Mycotoxins Legislation Worldwide., http://services.leatherheadfood.com/eman/FactSheet.aspx?I $\mathrm{D}=79$, Accessed; 07/07/2014.

[27] WHO, (2006). Impacts of aflatoxins on health and nutrition, Report of an expert group meetingBrazzaville, 24-27 may 2005.

[28] International Food Policy Research Institute, IFPRI. (2013). Aflatoxins: finding solutions for improved food safety, www.ifpri.org/.../aflatoxins-fi... Accessed; 2/7/2014. 